\title{
EFFECT OF CH4 EMISSION REDUCTION OF WATER, FERTILIZER AND BIOCHAR REGULATION METHOD ON A RICE FIELD IN THE NORTHEASTERN COLD AREA OF CHINA
}

\author{
LIN, Y. Y. ${ }^{1,2}-$ YI, S. J. ${ }^{2,3 *}-$ ZHANG, Z. X. ${ }^{4}-$ WANG, M. X. ${ }^{4}-$ NIE, T. Z. ${ }^{5}$ \\ ${ }^{1}$ College of Civil Engineering and Water Conservancy, Heilongjiang Bayi Agricultural \\ University, Heilongjiang Daqing 163319, China \\ ${ }^{2}$ Quality Supervision and Testing Center for Agricultural Processed Products of the Ministry of \\ Agriculture (Daqing), Heilongjiang Daqing 163319, China \\ ${ }^{3}$ College of Engineering, Heilongjiang Bayi Agricultural University, Heilongjiang Daqing \\ 163319, China \\ ${ }^{4}$ Key Laboratory of Efficient Use of Agricultural Water Resources, Ministry of Agriculture, \\ Harbin, Heilongjiang 150030, China \\ ${ }^{5}$ School of Water Conservancy and Electric Power Heilongjiang University, Harbin, \\ Heilongjiang 150080, China \\ *Corresponding author \\ e-mail: yishujuan_2005@yeah.net \\ (Received 24 $4^{\text {th }}$ Nov 2019; accepted $6^{\text {th }}$ May 2020)
}

\begin{abstract}
The objective of this study was to analyse the black soil rice fields of the northeastern cold region of China, D311 optimal design scheme with three factors secondary saturation was adopted and static opaque chamber - gas chromatographic method was utilized to analyze the effect of irrigation amount, nitrogen fertilizer and straw biochar on the emission of the greenhouse gas $\mathrm{CH}_{4}$ from rice fields, the study determined the optimal application scheme of water and fertilizer for emission control. The results show that the order of influence for these factors from the highest to the lowest is: biochar > nitrogen fertilizer > water; effect of irrigation amount on $\mathrm{CH}_{4}$ emission is increased at first, followed by a decrease. Increase of nitrogen fertilizer and biochar can significantly reduce $\mathrm{CH}_{4}$ emission loads; interaction between two factors has an inhibitory effect on $\mathrm{CH}_{4}$ emissions and it is shown as below: nitrogen fertilizer + biochar > water + biochar > water + nitrogen fertilizer; in combination with the yield, when emission reduction target of rice field $\mathrm{CH}_{4}$ is controlled at $20 \sim 40 \%$ of normal emission, the optimized application scheme in combination of water, fertilizer and biochar is the following: irrigation amount 4,930-5,310 $\mathrm{m}^{3} / \mathrm{hm}^{2}$, nitrogen application amount $96.93-107.74 \mathrm{~kg} / \mathrm{hm}^{2}$ and biochar application amount 19.71-24.12 t/hm².
\end{abstract}

Keywords: cold black soil, rice, irrigation and fertilization, biochar dosage, $\mathrm{CH}_{4}$ emission

\section{Introduction}

The reason for global warming lies in the increase of greenhouse gas concentration in the atmosphere. $\mathrm{CH}_{4}$ as an important greenhouse gas in the atmosphere has already contributed to as much as $15 \%$ for greenhouse effect. Hence, $\mathrm{CH}_{4}$ has become a key factor affecting global climate following $\mathrm{CO}_{2}$ (Wang, 2001; Jiang, 2001; Wang et al., 2008). Hence, rice fields are main anthropogenic source for $\mathrm{CH}_{4}$ emission. About $3.1 * 10^{10} \sim 1.12 * 10^{11} \mathrm{~kg}$ released annually from rice fields accounts for $5 \sim 19 \%$ proportion in $\mathrm{CH}_{4}$ emission load to the atmosphere (Zou et al., 2009; IPCC, 2007). 
Therefore, the reduction of greenhouse gas $\mathrm{CH}_{4}$ emission from rice fields has a great significance in mitigating climate change in China.

There are many factors affecting $\mathrm{CH}_{4}$ emission from rice fields. It is shown from the study that irrigation mode of rice fields plays an important role in $\mathrm{CH}_{4}$ emission. Compared with submerged irrigation, $\mathrm{CH}_{4}$ emission from rice fields under inadequate irrigation will be significantly reduced (Peng et al., 2010; Li et al., 2005). Similarly, fertilization measures have an important impact on $\mathrm{CH}_{4}$ emission from rice fields. It is shown from the study that the application of fertilizer can increase $\mathrm{NH}_{4}+-\mathrm{N}$ concentration, but growth of $\mathrm{CH}_{4}$ oxidizing bacteria is also promoted. The promoted $\mathrm{CH}_{4}$ oxidizing bacteria oxidize more $\mathrm{CH}_{4}$, which results in the reduction of $\mathrm{CH}_{4}$ emission from rice fields (Zou et al., 2005; Cai et al., 1997; Ma et al., 2007). Biochar can play an important role in the global carbon geochemical cycle, climate change and environmental system because of its strong ability of nitrogen and carbon fixation. It has become a hot topic in atmospheric science and environmental science fields (Liu, 2011.). The study shows that applying biochar to soil can significantly improve soil quality and permeability. While fixing atmospheric $\mathrm{CO}_{2}$, soil $\mathrm{CH}_{4}$ emission (Karhua et al., 2011; Qin et al., 2012) was also affected. Indoor pot experiments performed by Rondon showed that $\mathrm{CH}_{4}$ emission decreased by $20.4 \%$ (Rondon et al., 2007) when $2 \mathrm{~kg} / \mathrm{m}^{2}$ biochar was added to the soil for cultivation of forage and soybean.

At present, although many scholars have conducted in-depth studies on the effects of water, fertilizer and biochar management on $\mathrm{CH}_{4}$ emissions from rice fields (Shi et al., 2011; Yuan et al., 2008; Liang et al., 2004; Knoblauch et al., 2008; Xu et al., 2015), they are basically individual single-factor studies, but the effects of integrated management on $\mathrm{CH}_{4}$ emissions from rice fields (factor coupling effect) are rarely reported. The objective of this study was mainly to analyze the coupling effects of three factors water, nitrogen fertilizer and biochar on $\mathrm{CH}_{4}$ emissions from rice fields. In combination with $\mathrm{CH}_{4}$ emission reduction targets during rice growing reason, optimal water, fertilizer and biochar application schemes are sought so as to provide the field management technology reference for $\mathrm{CH}_{4}$ emission reduction in black soil rice fields in the cold area of Northeastern China.

\section{Materials and methods}

\section{Overview of experimental sites}

The experiment was carried out at the Rice Irrigation Test Center Station $\left(125^{\circ} 44^{\prime} \mathrm{E}, 45^{\circ} 63^{\prime} \mathrm{N}\right)$ in Heping Town, Qingan County, Suihua City, Heilongjiang Province from May to October, 2018, which is a typical cold black soil area. With $2.5^{\circ} \mathrm{C}$ annual mean temperature, $550 \mathrm{~mm}$ annual mean precipitation, $750 \mathrm{~mm}$ annual mean evaporation from water surface, 156 171 d hydrothermal growth period of crops and $128 \mathrm{~d}$ frost free period all year round, the area based on the climatic characteristics is classified as continental monsoon climate in cold temperature zone. As rice soil is an albic soil type, the soil here has $1.01 \mathrm{~g} / \mathrm{cm}^{3}$ unit weight and $61.8 \%$ porosity. The basic physicochemical properties of the soil are the followings: organic matter mass ratio $41.4 \mathrm{~g} / \mathrm{kg}, \mathrm{pH}$ value 6.40 , total nitrogen mass ratio $15.06 \mathrm{~g} / \mathrm{kg}$, total phosphorus mass ratio $15.23 \mathrm{~g} / \mathrm{kg}$, total potassium mass ratio $20.11 \mathrm{~g} / \mathrm{kg}$, alkali hydrolysis nitrogen mass ratio $154.36 \mathrm{mg} / \mathrm{kg}$, available phosphorus mass ratio $25.33 \mathrm{mg} / \mathrm{kg}$ and available potassium mass ratio $157.25 \mathrm{mg} / \mathrm{kg}$. 


\section{Experimental design}

Saturated D311 optimal design (Xu, 1997) is used in the experiment to study the effects of irrigation amount, nitrogen fertilizer and biochar on $\mathrm{CH}_{4}$ emission in rice growing season under controlled irrigation conditions. Water and fertilizer are applied based on the application standard of local farmers, namely $2,500 \sim 7,500 \mathrm{~kg} / \mathrm{hm}^{2}$ irrigation amount, $50-150 \mathrm{~kg} / \mathrm{hm}^{2}$ nitrogen fertilizer (pure nitrogen) and $0 \sim 40 \mathrm{t} / \mathrm{hm}^{2}$ biochar. The detailed design plan is shown in Tables 1 and 2.

Table 1. Encoding table for factor level

\begin{tabular}{c|c|c|c|c|c}
\hline \multicolumn{3}{c|}{ Encoding value } & \multicolumn{3}{|c}{ Practical value } \\
\hline $\mathbf{X}_{\mathbf{1}}$ & $\mathbf{X}_{\mathbf{2}}$ & $\mathbf{X}_{\mathbf{3}}$ & $\mathbf{W}\left(\mathbf{m}^{\mathbf{3}} / \mathbf{h m}^{\mathbf{2}}\right)$ & $\mathbf{N}\left(\mathbf{k g} / \mathbf{h m}^{\mathbf{2}}\right)$ & $\mathbf{B C}\left(\mathbf{t} / \mathbf{h m}^{\mathbf{2}}\right)$ \\
\hline 2 & 2 & 2 & 7500 & 150 & 40 \\
1.414 & 1.414 & 1 & 6800 & 135 & 30 \\
0 & 0 & 0 & 5000 & 100 & 20 \\
-1.414 & -1.414 & -1 & 3200 & 65 & 10 \\
-2 & -2 & -2 & 2500 & 50 & 0 \\
\hline
\end{tabular}

$\mathrm{W}(\mathrm{X} 1)$ - water, $\mathrm{N}(\mathrm{X} 2)$ - nitrogen fertilizer, BC (X3) - biochar

Table 2. Optimal design treatment table of saturated D-311

\begin{tabular}{|c|c|c|c|c|c|c|c|}
\hline \multirow{2}{*}{$\begin{array}{l}\text { Treatment } \\
\text { no. }\end{array}$} & \multicolumn{3}{|c|}{ Encoding value } & \multicolumn{3}{|c|}{ Practical value } & \multirow{2}{*}{$\begin{array}{c}\mathrm{CH}_{4} \underset{\left(\mathrm{kg} / \mathrm{hm}^{2}\right)}{\text { emission load }} \\
\end{array}$} \\
\hline & $\mathbf{X}_{1}$ & $\mathbf{X}_{2}$ & $\mathbf{X}_{3}$ & $\mathrm{~W}\left(\mathbf{m}^{3} / \mathbf{h m}^{2}\right)$ & $N\left(\mathrm{~kg} / \mathrm{hm}^{2}\right)$ & BC $\left(\mathbf{t} / \mathbf{h m}^{2}\right)$ & \\
\hline 1 & 0 & 0 & 2 & 5000 & 100 & 40 & 121.29 \\
\hline 2 & 0 & 0 & -2 & 5000 & 100 & 0 & 209.71 \\
\hline 3 & -1.414 & -1.414 & 1 & 3200 & 65 & 30 & 179.42 \\
\hline 4 & 1.414 & -1.414 & 1 & 6800 & 65 & 30 & 179.95 \\
\hline 5 & -1.414 & 1.414 & 1 & 3200 & 135 & 30 & 158.29 \\
\hline 6 & 1.414 & 1.414 & 1 & 6800 & 135 & 30 & 150.45 \\
\hline 7 & 2 & 0 & -1 & 7500 & 150 & 10 & 164.63 \\
\hline 8 & -2 & 0 & -1 & 2500 & 50 & 10 & 147.99 \\
\hline 9 & 0 & 2 & -1 & 5000 & 100 & 10 & 165.49 \\
\hline 10 & 0 & -2 & -1 & 5000 & 100 & 10 & 178.17 \\
\hline 11 & 0 & 0 & 0 & 5000 & 100 & 10 & 144.42 \\
\hline
\end{tabular}

$\mathrm{W}(\mathrm{X} 1)$ - water, N (X2) - nitrogen fertilizer, BC (X3) - biochar

Eleven treatments with three repetitions are arranged in randomized block. Each block covers a $10 \mathrm{~m} * 10 \mathrm{~m}=100 \mathrm{~m}^{2}$ area. Around the block, rice was also planted so as to add the protection line. With the same rice seedling raising, transplanting, plant protection, medication and other technical measures as well as field management conditions, the blocks were separated with impervious treatment measures to decrease the effect of lateral infiltration on the test, namely plastic sheets and cement ridges were used as seepage isolation materials around the blocks. They were buried $40 \mathrm{~cm}$ deep into the surface of the field. Pipeline water supply was adopted. Each pipeline was equipped with water meters so as to control the irrigation amount. Nitrogen fertilizer was applied according in 5:3:2 ratio of base fertilizer, tillering fertilizer and spike 
fertilizer. $\mathrm{P}$ fertilizer used as base fertilizer was applied at a time with $45 \mathrm{~kg} / \mathrm{hm}^{2}$ application amount. $\mathrm{K}$ fertilizer was applied twice as base fertilizer and 8.5 leaf age (panicle primordium differentiation stage) with $1: 1$ ratio. With $80 \mathrm{~kg} / \mathrm{hm}^{2}$ application amount, biochar was applied to the surface of the soil and then evenly mixed with plowing soil by rotary tiller. The tested fertilizers are urea (containing $\mathrm{N} \mathrm{46 \% ),}$ diammonium phosphate (containing $\mathrm{N} 18 \%$, containing $\mathrm{P}_{2} \mathrm{O}_{5} 46 \%$ ) and potassium fertilizer (containing $40 \% \mathrm{~K}_{2} \mathrm{O}$ ). The tested biochar is the s rice traw biochar product supplied by Liaoning Golden Future Agriculture Technology Co., Ltd. The physical and chemical data are shown in Table 3.

Table 3. Physicochemical data of rice straw biochar

\begin{tabular}{c|c|c|c|c|c|c|c|c}
\hline & $\mathbf{P H}(\mathbf{H 2 O})$ & $\begin{array}{c}\mathbf{C} \\
(\boldsymbol{\%})\end{array}$ & $\begin{array}{c}\mathbf{N} \\
(\boldsymbol{\%})\end{array}$ & $\begin{array}{c}\mathbf{P} \\
(\boldsymbol{\%})\end{array}$ & $\begin{array}{c}\mathbf{K} \\
(\boldsymbol{\%})\end{array}$ & $\begin{array}{c}\mathbf{C E C} \\
\left(\mathbf{c m o l}_{\mathbf{k g}} \mathbf{- 1}\right)\end{array}$ & $\begin{array}{c}\text { Surface area } \\
\left(\mathbf{m}^{\mathbf{2}} \cdot \mathbf{g}^{-\mathbf{1}}\right)\end{array}$ & $\begin{array}{c}\text { Void area } \\
\left(\mathbf{c m}^{\mathbf{3}} \cdot \mathbf{g}^{-\mathbf{1}}\right)\end{array}$ \\
\hline $\begin{array}{c}\text { Rice traw } \\
\text { biochar }\end{array}$ & 10.2 & 42.7 & 0.76 & 0.16 & 1.07 & 44.7 & 81.8 & 0.08 \\
\hline
\end{tabular}

The rice varieties tested were Longqing Rice No. 3 with the planting density of 4 plants per hole, 25 holes per square metre. Base fertilizer was applied on 6 May and transplantation was performed on 17 May. Tillering fertilizer was applied on 31 May, earing fertilizer was applied on 19 July and the rice was harvested on 20 September. $127 \mathrm{~d}$ growth period of rice was divided into period of seedling establishment (May 17May 30), tillering period (May 31-July 7), jointing and booting period (July 8-July 25), heading to flowering period (July 26-August 4), milk ripe period (August 5-August 24) and yellow ripening period (August 25-September 20).

\section{Gas collection and determination}

Gas sampling and selection were carried out on sunny days by static opaque chamber-gas chromatography method. The box is a cuboid with a cross section of $18 \mathrm{~cm}$ side length. It is made of plexiglass. Insulation material (sponge and aluminum foil) is pasted on the outside of the box to reduce the gas temperature change in the box caused by solar radiation during sampling. In the early growth stage, the box was $90 \mathrm{~cm}$ high and the box increased to $130 \mathrm{~cm}$ high after heading stage. A three-way valve gas recovery hole is on the box side $30 \mathrm{~cm}$ from the top connecting the three-way valve and gas collector. One fan is built at top of the sampling box so as to mix gas uniformly in the box during sampling. Before transplanting, a wooden base is placed in the sampling basin and aligned with the mud surface. During gas sampling, the sampling box is gently placed on the base of the concentric-circle-liked frame. The water in the base flume guarantees the gas isolation between the inside and outside of the sampling box during sampling. One week after rice transplantation, detection was started. The detection was performed from 10:00 to 12:00 (Li et al., 1998; Epstein and Burke, 1998). At each treatment, gas was collected for three times in parallel weekly until one week before harvest. About $100 \mathrm{~mL}$ gas in the box was extracted with a syringe during sampling. Samples were collected at 0, 5, 10 and 15 min, respectively. Afterwards, the gas in the syringe was transferred to the aluminium foil sampling bag immediately, and the sampling bag was brought back to the laboratory in time for determination.

Gas $\mathrm{CH}_{4}$ concentration was detected with Shimadzu GC-14B meteorological chromatograph along with hydrogen flame ionization detector (FID) and thermal 
conductivity detector (TCD) at $200{ }^{\circ} \mathrm{C}$ and $100{ }^{\circ} \mathrm{C}$ temperature. The separation materials were GDX-502 and Porapak Q, respectively and the column temperature was $100{ }^{\circ} \mathrm{C}$ and $55^{\circ} \mathrm{C}$. The standard gas was provided by the National Standard Materials Center. The gas collection device is shown in Figure 1.

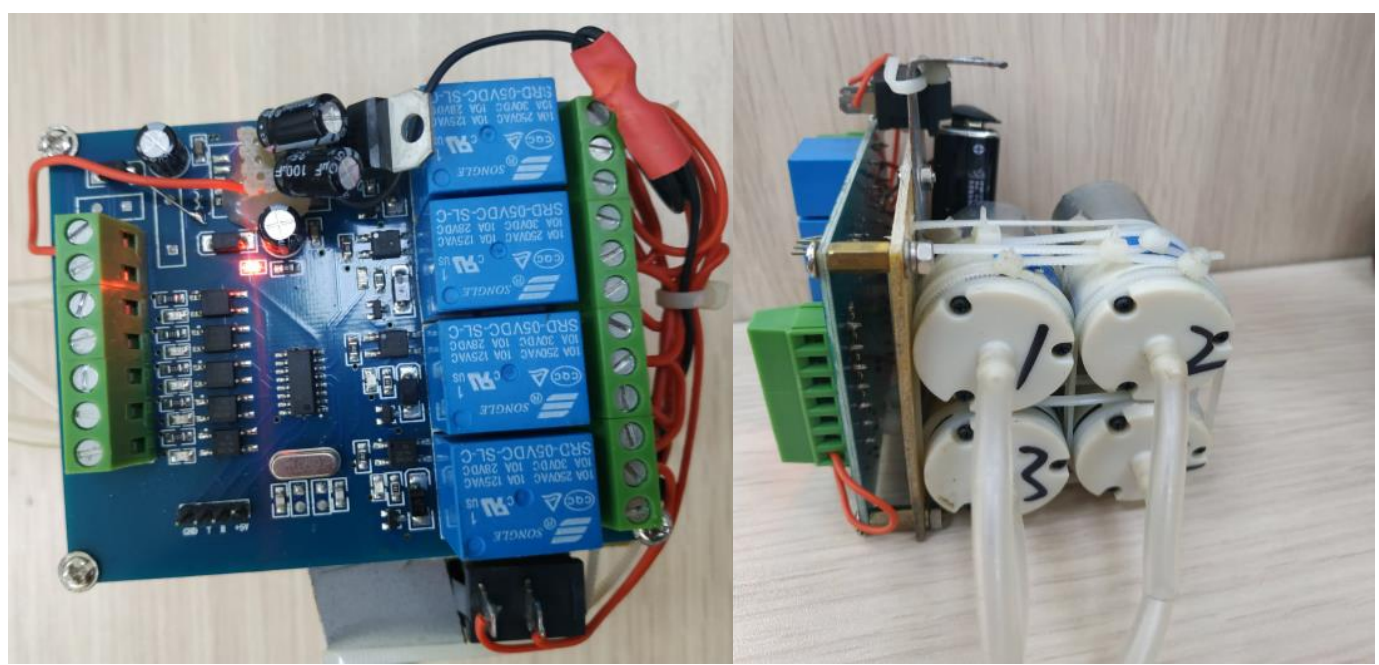

Figure 1. A device for automatically collecting static chamber greenhouse gases

\section{Calculation method and data analysis}

The following formula was used to calculate $\mathrm{CH}_{4}$ emission flux from rice field (Zheng et al., 1998): $\mathrm{F}=\rho \cdot \mathrm{h} \cdot \mathrm{dc} / \mathrm{dt} \cdot 273 /(273+\mathrm{T})$, where $\mathrm{F}$ is gas emission flux $\left(\mathrm{mg} \cdot \mathrm{m}^{-}\right.$ $\left.{ }^{2} \cdot \mathrm{h}^{-1}\right), \rho$ is gas density under standard state $\left(\mathrm{kg} \cdot \mathrm{m}^{-3}\right), \mathrm{h}$ is box height $(\mathrm{m})$, dc/dt is the gas concentration change rate in the sampling box $\left(\mathrm{mL} \cdot \mathrm{m}^{-3} \cdot \mathrm{h}^{-1}\right), 273$ is the gas equation constant and $\mathrm{T}$ is the average temperature in the sampling box during the sampling process $\left({ }^{\circ} \mathrm{C}\right)$. According to the relationship curve between gas concentration and time, the gas emission flux was calculated. The emission load during the growing season was the accumulated products of average flux value of each growing period and total duration in the growing period (Singh et al., 1996).

The data were analyzed with Excel 2003, SPSS 17.0 and MATLAB 7.0, using regression analysis and variance analysis to process the experimental data.

\section{Results and analysis}

\section{Emission load effect function of $\mathrm{CH}_{4}$ in growing season}

The coding values $\mathrm{X}_{1}(\mathrm{~W}), \mathrm{X}_{2}(\mathrm{~N})$ and $\mathrm{X}_{3}(\mathrm{C})$ in Table 1 were taken as independent variables and the average emission value of $\mathrm{CH}_{4}$ in the growing season in Table 2 were taken as the dependent variables for quadratic polynomial regression analysis so as to obtain the regression equation among $\mathrm{CH}_{4}$ emissions load, irrigation amount, nitrogen fertilizer and biochar. 
$F$ test was performed for the regression equation: $\left.F=5.16>\left(F_{0.01}(10,20)\right)=3.37\right)$. The regression equation has a very significant relationship, that is the equation can reflect the relationship among $\mathrm{CH}_{4}$ emission load in growing season and irrigation amount, nitrogen fertilizer and biochar. The absolute value of the first term coefficient of the regression equation is the basis for judging the influence degree of each factor on $\mathrm{CH}_{4}$ emission. Therefore, the influence degree of the equation on $\mathrm{CH}_{4}$ emission load from high to low was biochar, nitrogen fertilizer and water.

\section{Single factor effect analysis}

"Dimension reduction method" was adopted for the above main effect model. Any two factors were fixed at zero code value so as to determine the influencing effect of a single factor on the emission load of $\mathrm{CH}_{4}$ during the growing season, and then respectively obtain single-factor effect equation and draw single-factor effect curve (Eq. 2).

$$
\begin{gathered}
\mathrm{Y}_{1}=161.92+1.43 \mathrm{X}_{1}-5.05 \mathrm{X}_{1}^{2} \\
\mathrm{Y} 2=161.92-6.05 \mathrm{X}_{2}-1.21 \mathrm{X}_{2}^{2} \\
\mathrm{Y} 3=161.92-10.31 \mathrm{X}_{3}+0.57 \mathrm{X}_{3}^{2}
\end{gathered}
$$

It can be observed from Figure 2 that within the coding value range, the effect from irrigation amount on $\mathrm{CH}_{4}$ emission amount is promoting at first and then restraining. Increase of nitrogenous fertilizer and charcoal can significantly restrain $\mathrm{CH}_{4}$ emission load.

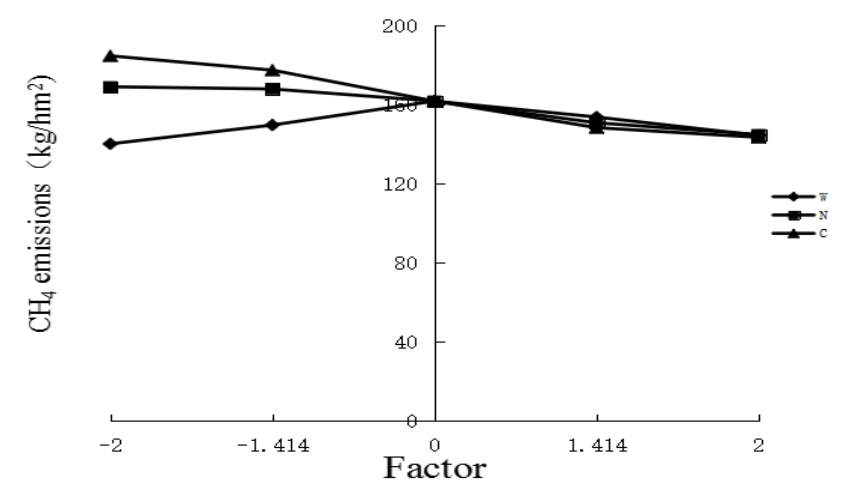

Figure 2. Single-factor effect curve diagram. (X1 - water, X2 - nitrogen fertilizer, X3 - biochar)

\section{Interactive effect analysis of factor}

Any factor is fixed at zero code value to obtain the interactive effect equation of two other factors and the equation is shown below:

$$
\begin{aligned}
& Y_{12}=161.92+1.43 X_{1}-6.05 X_{2}-1.05 X_{1} X_{2}-5.05 X_{1}^{2}-1.21 X_{2}^{2} \\
& Y_{13}=161.92+1.43 X_{1}-10.31 X_{3}-2.73 X_{1} X_{3}-5.05 X_{1}^{2}-0.57 X_{3}^{2} \\
& Y_{23}=161.92-6.05 X_{2}-10.31 X_{3}-2.89 X_{2} X_{3}-1.21 X_{2}^{2}-0.57 X_{3}^{2}
\end{aligned}
$$


A diagram is drawn for the interactive effect equation of these two factors (Fig. 3). It can be seen from Figure 3, the interaction between two factors has an inhibitory effect on $\mathrm{CH}_{4}$ emission and the effect degree on $\mathrm{CH}_{4}$ emission load from high to low is as follows: nitrogen fertilizer + biochar, water + biochar and water + nitrogen fertilizer. As can be seen from Figure $3 a$ and $b$, when irrigation amount is fixed at a certain level, $\mathrm{CH}_{4}$ emission load decreases with the increase of the application of nitrogen fertilizer and biochar. However, when nitrogen fertilizer or biochar is fixed at a certain level, the effect of irrigation amount on $\mathrm{CH}_{4}$ emission increases or decreases and no obvious emission reduction can be obtained; it can be observed from Figure $3 c$ that with increase in application quantity of nitrogen fertilizer and biochar, $\mathrm{CH}_{4}$ emission decreased significantly. Thus, increase of biochar application quantity has a significant effect on $\mathrm{CH}_{4}$ emission reduction effect.

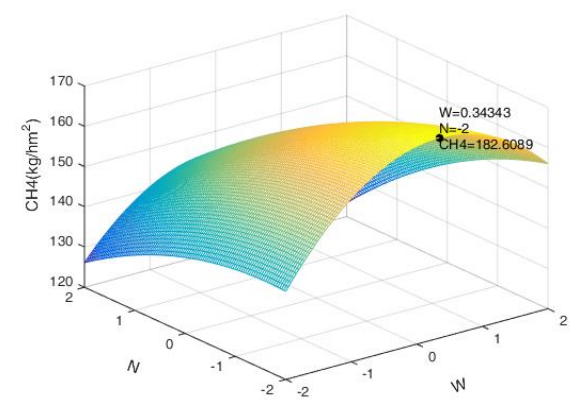

$\mathrm{a}$

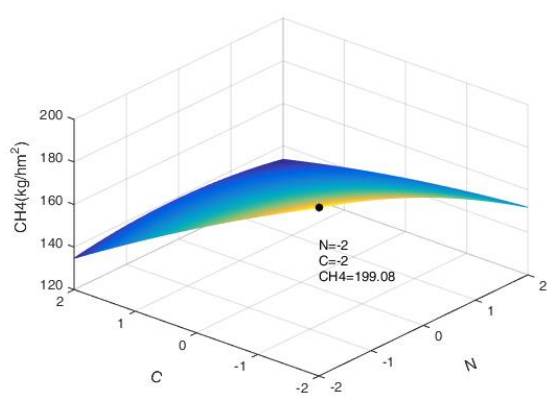

$\mathrm{c}$

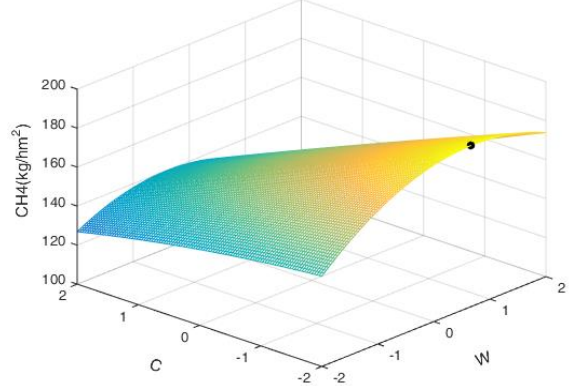

b

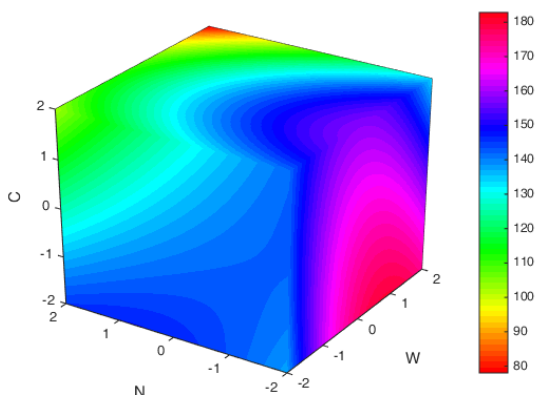

d

Figure 3. Interactive effect analysis between two factors related to emission load of methane in growing season. Interactive effect curve diagram between (a) irrigation amount and nitrogenous fertilizer, (b) irrigation amount and biochar and (c) nitrogenous fertilizer and biochar. (d) Interactive effect four-dimension diagram among irrigation amount, nitrogenous fertilizer and biochar. ( $W$ - water, $N$ - nitrogen fertilizer, $C$ - biochar)

\section{Analysis for management and optimization plan of water, fertilizer and biochar}

Frequency analysis method was used to optimize the main effect model. The coding values were divided into five levels $(-2,-1.414,0,1.414,2)$ within the experimental design range to constitute $\mathrm{T}=5^{3}=125$ treatment combinations. Combining with the yield, the emission reduction target of $\mathrm{CH}_{4}$ in rice fields during the growing season was controlled within $20-40 \%$, because all the factors of treatment No. 11 are at zero level in this experiment, so they are regarded as normal treatment, that is, 60 80\% (86.65 115.54 kg/hm ${ }^{2}$ ) normal emission load of $\mathrm{CH}_{4}$ in growing season was selected for frequency analysis to obtain 50 optimization results for the management simulation 
equation between water fertilizer and biochar in $\mathrm{CH}_{4}$ emission load during the growing season. Frequency analysis of gas emission flux is shown in Table 4.

Table 4. Water and fertilizer and biochar application plan with $\mathrm{CH}_{4}$ emission of $86.65 \sim 115.54 \mathrm{~kg} / \mathrm{hm}^{2}$ in the rice growing season

\begin{tabular}{|c|c|c|c|c|c|c|}
\hline \multirow{2}{*}{ Coding value } & \multicolumn{2}{|c|}{ Irrigation amount } & \multicolumn{2}{|c|}{ Nitrogenous fertilizer } & \multicolumn{2}{|r|}{ Biochar } \\
\hline & Times & Frequency $/ \%$ & Times & Frequency/\% & Times & Frequency/\% \\
\hline-2 & 9 & 18 & 9 & 18 & 4 & 8 \\
\hline-1.414 & 9 & 18 & 10 & 20 & 12 & 24 \\
\hline 0 & 9 & 18 & 9 & 18 & 21 & 42 \\
\hline 1.414 & 10 & 20 & 10 & 20 & 8 & 16 \\
\hline 2 & 13 & 27 & 12 & 24 & 5 & 10 \\
\hline \multirow{2}{*}{ Average value } & \multicolumn{2}{|r|}{0.19} & \multicolumn{2}{|r|}{0.08} & \multicolumn{2}{|r|}{0.09} \\
\hline & \multicolumn{2}{|r|}{0.11} & \multicolumn{2}{|r|}{0.11} & \multicolumn{2}{|r|}{0.08} \\
\hline $\begin{array}{c}\text { Standard error confidence } \\
\text { interval }(95 \%)\end{array}$ & \multicolumn{2}{|c|}{$-0.0564 \sim 0.2480$} & \multicolumn{2}{|c|}{$-0.1230 \sim 0.3094$} & \multicolumn{2}{|c|}{$-0.0287 \sim 0.4124$} \\
\hline Optimal plan $\left(\mathrm{kg} / \mathrm{hm}^{2}\right)$ & \multicolumn{2}{|c|}{$4930 \sim 5310$} & \multicolumn{2}{|c|}{$96.93 \sim 107.74$} & \multicolumn{2}{|c|}{$19.71 \sim 24.12$} \\
\hline
\end{tabular}

\section{Discussion}

Irrigation amount has an important influence on $\mathrm{CH}_{4}$ emission load from rice fields. It is shown from the study that relatively small irrigation amount can promote gas exchange between soil and atmosphere, destroy the anaerobic conditions of soil and inhibit the activity for production of $\mathrm{CH}_{4}$ bacteria. However, increase of soil aeration promotes $\mathrm{CH}_{4}$ emission directly into the atmosphere to a certain extent. Whereas, in case of sufficient water quantities, the rice field will keep a deep water layer for long time. The air and soil is blocked by water layer, which may close some stomata and reduce $\mathrm{CH}_{4}$ emissions via plants (Ding, 1997; National Information Bulletin on Climate Change of the People's Republic of China, 2004). This is consistent with the study results.

Nitrogen fertilizer application amount $\mathrm{CH}_{4}$ has an important influence on $\mathrm{CH}_{4}$ emission from rice field. The experimental results showed that the nitrogen fertilizer applied has obviously a negative effect on $\mathrm{CH}_{4}$ emission load from black soil rice field in the growing season, which is basically consistent with the results of Shangguan et al. (1996) and others think that urea could reduce $\mathrm{CH}_{4}$ emission of rice fields. However, Liang et al. (2002) and others believe that urea has different effects on $\mathrm{CH}_{4}$ release (promoting or inhibiting), possibly because it can increase the soil $\mathrm{pH}$ value. In most cases, When urea was applied to acid soil, the increase of $\mathrm{pH}$ value of soil became favorable to the formation of $\mathrm{CH}_{4}$, Whereas, most black soils are neutral and alkaline. After urea is applied to neutral and alkaline soils, increased $\mathrm{pH}$ value restrains formation of $\mathrm{CH}_{4}$. Therefore, the effect of nitrogen fertilizer application on $\mathrm{CH}_{4}$ emission of rice fields requires to be further studied.

The results show that biochar application can effectively reduce $\mathrm{CH}_{4}$ emission load of rice fields. The reason may be that input of biochar effectively improves soil aeration, reduces soil water-soluble organic carbon content, thus improving soil fertility. In addition, biochar input as a carbon source can provide sufficient matrix for $\mathrm{CH}_{4}$ oxidizing bacteria and reduce $\mathrm{CH}_{4}$ emissions via oxidation (Liang et al., 2002). 


\section{Conclusion}

(1) Water, nitrogen and biochar have different degree of effects on $\mathrm{CH}_{4}$ emission load of rice fields during growing season. The analysis results show that the effects of three factors on $\mathrm{CH}_{4}$ emission load are as follows: biochar > nitrogen fertilizer > water; effects of irrigation amount on $\mathrm{CH}_{4}$ emissions are increase at first and then decrease. Increase of nitrogen fertilizer and biochar can significantly reduce $\mathrm{CH}_{4}$ emission load.

(2) The interaction of two factors can inhibit $\mathrm{CH}_{4}$ emission during growing season. The results show that the effects on $\mathrm{CH}_{4}$ emissions are as follows: nitrogen fertilizer + biochar $>$ water + biochar $>$ water + nitrogen fertilizer; when irrigation amount is fixed at a certain level, $\mathrm{CH}_{4}$ emission amount decreases with the increase of application amount of nitrogen fertilizer and biochar. However, when nitrogen fertilizer or biochar is fixed at certain level, the increase of irrigation amount may cause $\mathrm{CH}_{4}$ emission load increase or decrease. There is no obvious emission reduction effect. With increase of application amount of nitrogen fertilizer and biochar, $\mathrm{CH}_{4}$ emission amount decreased significantly. Thus, increase in application amount of biochar has an obvious effect on $\mathrm{CH}_{4}$ emission reduction.

(3) In combination with the yield, it is to reduce $\mathrm{CH}_{4}$ emission load of rice fields in the growing season is controlled from 20 to $40 \%$. The frequency analysis method is used to optimize the main effect model. The optimized combined application plan of water, fertilizer and biochar was determined as follows: irrigation amount 4,930 5,310 $\mathrm{m}^{3} / \mathrm{hm}^{2}$, nitrogen application amount $96.93 \sim 107.74 \mathrm{~kg} / \mathrm{hm}^{2}$ and biochar quantity $19.71 \sim 24.12 \mathrm{t} / \mathrm{hm}^{2}$.

In this study, we tried to add biochar into the soil to realize joint coupling with water and fertilizer, and established a mathematical model of $\mathrm{CH}_{4}$ emission load during the growing season of rice fields in the Northeast of China about water, nitrogen and biochar. The model can reflect the relationship between $\mathrm{CH}_{4}$ emission from rice field and water, fertilizer and biochar through significance test, so as to make quantitative research on water, fertilizer and biochar more convenient. Therefore, the research has a good application prospect. However, the coupling effects of water, fertilizer and biochar on seasonal $\mathrm{CH}_{4}$ emissions of rice fields have only been preliminarily discussed in this paper, but no qualitative research has been carried out. In the process of further in-depth study, data of different growth stages for many years should be accumulated to make the model more perfect with practical guiding significance.

Acknowledgments. Thank you for the support from Common Subsidy Scheme for Postdoctor of Heilongjiang Province (LBH-Z18255), Heilongjiang Bayi Agricultural University Support Program for San Heng San Zong (TDJH201803), Talent Introduction Plan of Heilongjiang Bayi Agricultural University (XYB201801), Postdoctor Work Station for Agricultural Processed Product Quality Supervision and Inspection Test Center (Daqing) of Ministry of Agriculture.

\section{REFERENCES}

[1] Cai, Z. C., Xing, G. X., Yan, X. Y., Xu, H., Tsuruta, H., Yagi, K., Minami, K. (1997): Methane and nitrous oxide emissions from rice paddy fields as affected by nitrogen fertilizers and water management. - Plant and Soil 196(1): 7-14.

[2] Ding, Y. H. (1997): IPCC main scientific achievements and problems for scientific assessment report about the second climate change. - Advances in Earth Science 12(2): $158-163$ 
[3] Epstein, H. E., Burke, L. C. (1998): Plant functional type effects on trace gas fluxes in the short grass steppe. - Biogeochemistry 42(1-2): 145-168.

[4] IPCC (2007): Climate Change 2007: Mitigation of Climate Change. - Contribution of Working Group III to the Fourth Assessment Report of The Intergovernmental Panel on Climate Change. Cambridge University Press, Cambridge, pp. 63-67.

[5] Jiang, Y. (2001): Grainfield is pure emission ground of greenhouse gases. Environmental Science of China 21(2): 136.

[6] Karhua, K., Mattila, T., Bergström, I., Kristiina, R. (2011): Biochar addition to agricultural soil increased $\mathrm{CH}_{4}$ uptake and water holding capacity - results from a shortterm pilot field study. - Agriculture, Ecosystems and Environment 140(31): 309-313.

[7] Knoblauch, C., Marifaat, A. A., Haefele, M. S. (2008): Biochar in rice-based system: impact on carbon mineralization and trace gas emissions. - Bioresource Technology 95(32): 255-257.

[8] Liang, B. C., Wang, X. L., Ma, B. L. (2002): Maize root-induced change in soil organic carbon pools. - Soil Science Society of America Journal 66(13): 845-847.

[9] Liang, W., Zhang, Y., Yue, J., Wu, J., Shi, Y., Huang, G. H. (2004): Effect of long-term nitrogen application on emission of $\mathrm{CH}_{4}$ and $\mathrm{N}_{2} \mathrm{O}$ from black soil water and dry land. Journal of Ecology 23(3): 44-48.

[10] Li, D. X., Peng, S. Z., Xu, J. Z., Ding, J. L., He, Y., Yu, J. Y. (2005): Ecological and environmental effect of rice field under water-saving irrigation condition. - Journal of Hohai University (Natural Science Edition) 33(6): 629-633.

[11] Li, J., Wang, M. X., Cheng, D. Z. (1998): Selection of sampling time for non-continuous measurement of methane emission from rice fields. - Journal of Graduate School of Chinese Academy of Sciences 15(1): 24-29.

[12] Liu, Y. X. (2011): Effect of Biomass Carbon Input on Soil Nitrogen Erosion and Greenhouse Gas Emission Characteristics. - Zhejiang University, Hangzhou.

[13] Ma, J., Li, X. L., Xu, H., Han, Y., Cai, Z. C., Yagi, K. (2007): Effects of nitrogen fertilizer and wheat straw application on $\mathrm{CH} 4$ and $\mathrm{N} 2 \mathrm{O}$ emissions from a paddy rice field. - Australian Journal of Soil Research 45(5): 359-367.

[14] National Information Bulletin on Climate Change of the People's Republic of China. (2004): National Information Bulletin on Climate Change. - China Planning Press, Beijing.

[15] Peng, S. Z., Yang, S. H., Xu, J. Z. (2010): Influence from control irrigation on comprehensive emissions of $\mathrm{CH}_{4}$ and $\mathrm{N}_{2} \mathrm{O}$ from rice field along with greenhouse effect. Advances in Water Science 21(2): 235-240.

[16] Qin, X. B., Li, Y. E., Wan, Y. F., Shi, S. W., Liao, Y. L., Liu, Y. T., Li, Y. (2012): Effect from rice straw returning way on greenhouse gas emission strength under no-tillage condition. - Journal of Agricultural Engineering 28(6): 210-216.

[17] Rondon, M. A., Lehmann, J., Ramirez, J., Pilar, M. (2007): Biological nitrogen fixation by common beans (Phaseolus vulgaris L) increases with bio-char additions. - Biology and Fertility of Soils 43(13): 699-708.

[18] Shangguan, X. J., Wang, M. X. (1996): Transmission of Rice Field $\mathrm{CH}_{4}$. - China Environmental Science Press, Beijing.

[19] Shi, S. W., Li, Y. E., Wan, Y. F., Qin, X. B., Gao, Q. Z. (2011): Emission of $\mathrm{CH}_{4}$ and $\mathrm{N}_{2} \mathrm{O}$ from double cropping rice field under different nitrogen and phosphate fertilizer dosage. - Environmental Science 32(7): 1899-1907.

[20] Singh, J. S., Sing, S., Raghubanshi, A. S., Singh. S., Kashyap, A. K. (1996): Methane flux from rice /wheat agroecosystem as affected by crop phenology, fertilization and water lever. - Plant and Soil 183(2): 323-327.

[21] Wang, F., Li, Y. H., Zhao, T. C., Chen, C. (2008): Ningxia $\mathrm{CO}_{2}, \mathrm{CH}_{4}, \mathrm{~N}_{2} \mathrm{O}$ greenhouse gas emission estimation and emission reduction measures. - Resources and Environment of Arid Region 22(11): 73-77. 
[22] Wang, M. X. (2001): Methane Emission from Rice Field of China. - Science Press, Beijing, pp. 85-87.

[23] Xu, D., Zhang, Z. X., Lin, Y. Y. (2015): Pot experiment for water and fertilizer optimization for control and emission of $\mathrm{CH}_{4}$ from black soil rice field. - Resources and Environment of Arid Area 29(4): 172-177.

[24] Xu, Z. R. (1997): Regression Analysis and Test Design. - China Agriculture Press, Beijing, pp. 102-143.

[25] Yuan, W. L., Cao, C. G., Cheng, J. P., Xie, N. N. (2008): Evaluation for $\mathrm{CH}_{4}$ and $\mathrm{N}_{2} \mathrm{O}$ emission and greenhouse effect under intermittent irrigation model. - Chinese Agricultural Science 41(12): 4294-4300.

[26] Zheng, X. H., Wang, M. X., Wang, Y. S., Shen, R. X., Li, J. (1998): Comparison of manual and automatic methods for measurement of methane emission from rice paddy fields. - Advances Atmospheres Science 15(4): 569-579.

[27] Zou, J. W., Huang, Y., Jiang, J. Y., Zheng, X. H., Sass, R. L. (2005): A 3-year field measurement of methane and nitrous oxide emissions from rice paddies in China: effects of water regime, crop residue, and fertilizer application. - Global Biogeochemical Cycles 19(2): 20-21.

[28] Zou, J. W., Huang, Y., Qin, Y. M., Liu, S. W., Shen, Q. R., Pan, G. Y., Lu, Y. Y., Liu, Q. H. (2009): Changes in fertilizer-induced direct N2O emissions from rice fields during rice-growing season in China between 1950s and 1960s. - Global Change Biology 15(21): 229-242. 